\title{
Serum Alkaline Phosphatase Types in North American Indians and Negroes
}

\author{
J. C. ROBINSON, C. LEVENE, B. S. BLUMBERG, and J. E. PIERCE \\ From the Biomedical Sciences Laboratory, Mental Retardation Program, National Institute of Child Health and \\ Human Development, Bethesda, Maryland, and The Institute for Cancer Research, Philadelphia, \\ Pennsylvania, U.S.A.
}

Recent investigations have revealed a correlation between human serum alkaline phosphatase types, the $\mathrm{ABO}$ blood groups, and the secretion of $\mathrm{ABH}$ substance in the saliva (Arfors, Beckman, and Lundin, 1963a, b; Shreffler, 1964; Beckman, 1964; Evans, 1965; Bamford, Harris, Luffman, Robson, and Cleghorn, 1965).

Arfors et al. (1963a) reported that phosphatase type 2 ( $\mathrm{Pp} 2$ ) was uncommon in people having blood group A. Beckman (1964) also demonstrated that the frequency of $\mathrm{Pp} 2$ was correlated with the $\mathrm{ABO}$ blood groups, being present in $30 \%$ of group $\mathrm{O}$ and B subjects, $15 \%$ of $A B$, and only $2 \%$ of the $A$ group. In contrast with results given by Shreffler (1964), Beckman did not find a significant difference in the frequency of $\mathrm{Pp} 2$ between $A_{1}$ and $A_{2}$ subjects.

The association of phosphatase types with the secretor phenomenon was originally suggested by Arfors et al. (1963b) because of the highly significant correlation of phosphatase type with the Lewis red blood cell groups. It has been shown that in adults, Le $(a-b+)$ subjects are salivary secretors on $\mathrm{ABH}$ substance; those who are $\mathrm{Le}(\mathrm{a}+\mathrm{b}-)$ are non-secretors; and those who are Le $(a-b-)$ are usually, but not invariably, secretors (Race and Sanger, 1962). Arfors et al. (1963b) examined group $O$ donors and found that the sera from all 16 Le $(a+b-)$ subjects, presumably non-secretors, formed a single major zone in starch gel zymograms stained for phosphatases (phosphatase type 1, Pp 1). Of 41 sera from Le $(a-b+)$ subjects, presumably secretors, 30 produced in addition a less rapidly migrating zone (phosphatase type 2, $\mathrm{Pp} 2$ ). Shreffler (1964) found that amongst the secretors of ABH substances, $P p 2$ was present in decreasing amount according to the $\mathrm{ABO}$ blood group: $\mathrm{O}$ or $\mathrm{B}>\mathrm{A}_{2}$

Received August 1, 1966.
$>A_{1}$. Little or none of the type $\operatorname{Pp} 2$ was demonstrated in the serum from non-secretors.

No significant association exists between the phosphatase type and the following: sex, MNSs, $\mathrm{Rh}, \mathrm{Kell}, \mathrm{Kidd}, \mathrm{Lutheran}$, and $\mathrm{P}$ blood groups; and haptoglobin, $\mathrm{Gm}$, and Gc serum protein types (Arfors et al., 1963a; Shreffler, 1964, 1965; Beckman, 1964). Shreffler (1965) found no association with the Duffy blood group; Beckman (1964), however, reported that the Pp 2 was higher in Fy $(\mathrm{a}+)$ subjects.

Association between serum alkaline phosphatase and blood groups has been demonstrated in cattle (Rendel and Gahne, 1963) and in sheep (Rendel and Stormont, 1964; Rendel, Aalund, Freedland, and Møller, 1964). A confirmation of this association in sheep, corroborated with family studies, was performed by Rasmusen (1965).

Robinson and Pierce (1964) demonstrated a differential susceptibility of the two phosphatase bands to the action of neuraminidase. The mobility of the fast band is decreased by incubation with neuraminidase; the mobility of the slow band is unaffected. The decrease of anodal migration results from a decrease in negative charge on the phosphatase as a consequence of the splitting off of neuraminic acid which has a free carboxyl group.

Using the neuraminidase technique, we examined serum samples from two American Indian populations (Montagnaise and Naskapi). Of the 267 sera examined, 10 contained a phosphatase band which, before incubation with neuraminidase, occupied the same zone as, and was indistinguishable from, the usual fast band. This component underwent a comparatively less marked decrease in mobility as a result of incubation with neuraminidase. It has been shown (Robinson, Pierce, and Blumberg, 1966) that this pattern is characteristic of a pregnancyassociated alkaline phosphatase, which has been 
previously described by Boyer (1961), using a different technique. Variations of alkaline phosphatase seen in pregnant women have been studied by Beckman and Grivea (1965).

\section{Materials and Methods}

Serum Specimens. Blood samples were taken into sterile vacutainer tubes (Becton Dickinson Co.) containing no anticoagulant, and were stored at $4^{\circ} \mathrm{C}$. The serum was separated within 4 days and stored in glass bottles at $-20^{\circ} \mathrm{C}$. until tested.

\section{Composition of the Populations}

The Naskapi and Montagnais Indians. The Naskapi, Montagnais, and Eastern Crees who belong to the Algonkian linguistic group are found at present living in Quebec and Labrador. Most ethnologists consider that they have, in spite of their differences, an essential identity (Harper, 1964). These Indians never formed tribes in the usual sense, and formerly lived by hunting and fishing, each group breaking off into small bands of one or a few families, to wander in the region familiar to them.

The Montagnais occupied the St. Lawrence escarpment and the southern portion of the interior, and the Naskapis lived north of them as far as the forest extends. The two groups have been separated by the polarizing effect of the fur trade, and have grown apart by marked differences in cultural associations, education, acculturation, and religion. For about 300 years the Montagnais have been tributary to trading and mission stations along the shores of the St. Lawrence river. They are said to have a substantial admixture of European blood. Most are Roman Catholics and are literate in French as well as their own language. Before 1865, the Naskapis visited the St. Lawrence stations, but since that time they have depended almost exclusively on trading posts and missions operated by English-speaking persons in the region of Ungava Bay. Owing to this remoteness, there has not been any significant admixture with Europeans. They are literate in their own tongue, and have accepted the religion of the Anglican missions.

The establishment of an iron-mining centre in the interior of the Labrador Peninsula has had the effect of accidentally uniting the separated groups. Upon completion of a railway from Sept Iles to Schefferville, some 30 Montagnais families moved to Schefferville, and many commute seasonally according to opportunities of employment.

The Naskapis have been reduced in the past 150 years by starvation and disease. One remnant group hunted near Fort McKenzie, and when this closed in 1948 they moved to Fort Chimo. During the summer of 1956, due to the efforts of the Indian Affairs Branch of the Department of Citizenship and Immigration, the Naskapis moved to Schefferville and settled near the Montagnais. A preliminary language difficulty was readily overcome, but there has been little intermarriage between them owing chiefly to religious convictions strongly held by each group (Blumberg, Martin, Allen, Weiner, Vitagliano, and Cooke, 1964).

The Sapelo Island Negroes. Sapelo Island lies off the coast of Georgia and constitutes one of the 'Sea Island' group. The small (approximately 250) American Negro population who live there have had relatively little contact with the mainland until recent years. There have been very few inhabitants of European descent resident on the island and there is said to be little gene mixture in this group. They will be discussed in greater detail in a forthcoming monograph (Blumberg, 1967).

Of the approximately 200 Naskapis, 153 blood samples were collected, and of between 350 to 400 Montagnais, 114 blood samples were collected. 79 specimens of blood from the Sapelo Island community were examined.

Phosphatase Zymograms. Mixtures consisting of $0.05 \mathrm{ml}$. serum and an equal volume of Vibrio cholerae neuraminidase (Behringwerke, A.G., Marburg, Germany) were incubated 20 hours at $37^{\circ} \mathrm{C}$. Horizontal starch gel electrophoresis (Smithies, 1955; Poulik, 1957) of the incubation mixtures was performed, together with corresponding serum samples. The phosphatase bands were more sharply defined when electrophoresis was limited to the time required for the brown 'borate-line' to reach $4 \cdot 0-4.5 \mathrm{~cm}$. beyond the insertions. The method for staining was the same as that used by Arfors et al. (1963a).

Blood Group and Secretion Typing. The typings for the blood groups and salivary secretion of $A B H$ and Lewis substance were performed by Dr. Fred H. Allen, Jr., at the Blood Grouping Laboratory, Boston, Massachusetts. The blood groups of the Naskapi and Montagnais Indians were reported by Blumberg et al. (1964).

\section{Results}

The Figure shows the typical results of phosphatase groups in starch gel, both with and without prior treatment with neuraminidase.

The frequency of phosphatase group 2 ( $P p 2$ ) in the Montagnais, Naskapi, and Sapelo populations is given in Table I.

The highest frequencies are in the Montagnais and Naskapi Indians, being $71.9 \%$ and $68.6 \%$, respectively. The frequency of $\mathrm{Pp} 2$ in the Sapelo population was $63.3 \%$.

The results shown in Table II confirm the relation between the phosphatase groups and the ABO blood groups in all three populations we have examined.

In the Montagnais (total 114), 82 persons were found to belong to phosphatase group $2(\operatorname{Pp} 2)$, and 


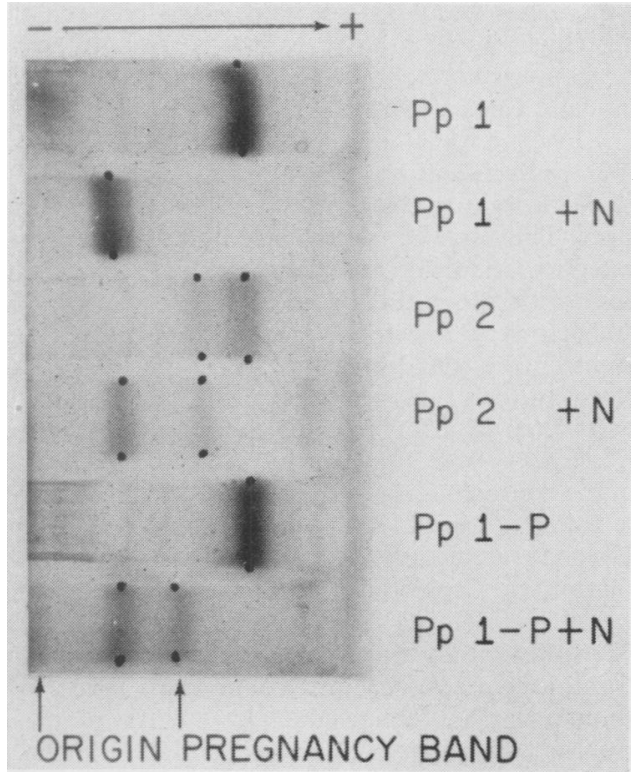

Fig. Serum alkaline phosphate zymogram. Type 1 phosphatase (Pp 1) appears as a single band; type 2 ( $P p$ 2) as double bands. Incubation with neuraminidase $(N)$ affects the mobility of the fast band, but not that of the slow band. $P p$ 1-P is a pregnancy serum. Incubation of pregnancy serum, either $\mathrm{Pp} 1-\mathrm{P}$ or $\mathrm{Pp} 2-\mathrm{P}$, results in the appearance of the pregnancy band (Robinson et al., 1966). The arrow at the top of the gel indicates that migration is toward the anode at the right. The ends of the stained (purple) phosphatase bands have been marked to distinguish them on black and white prints from the non-specifically stained (brown) bands of other proteins. of these, 70 were of blood group O. A total of 153 persons was examined in the Naskapi, and of the 105 typed as $\mathrm{Pp} 2$, there were 92 with blood group O. A similar state of affairs was seen in the Sapelo sample where out of a total of 78 persons examined, 49 were $\mathrm{Pp} \mathrm{2}$, and 38 of these were group $\mathrm{O}$.

This association between $\mathrm{Pp} 2$ and the $\mathrm{O}$ blood group is more striking when all subjects with blood group $A(A+A B)$ are compared with all those without blood group $A(O+B)$. In each population sample a $p$ value of $<0.0005$ was obtained.

Examination of the Lewis blood groups and $\mathrm{ABH}$ and Lewis secretion in the saliva (Table III) confirms the results of previous authors.

In the Montagnais and Sapelo Islanders the Pp 2 is absent or in low frequency in those people who are $\operatorname{Le}(a+b-)(p<0.0005$ and $0.005>p>0.001$, respectively). There were no Le $(a+b-)$ subjects amongst the Naskapi.

Results on $\mathrm{ABH}$ and Lewis secretion in the saliva are available for the Sapelo population only (Table IV).

There is an increased frequency of $\mathrm{Pp} 2$ in $\mathrm{ABH}$ secretors $(0.001>p>0.0005)$. There is also an increased frequency of $\mathrm{Pp} 2$ in Lewis substance secretors, but the difference is not considered significant $(0.05>p>0.025)$.

There was no association of the MNSs, Kidd (Jk), Sutter (Js), Xg, and Duffy $\left(F^{a}{ }^{a}\right)$ red blood cell groups, nor with the Gc serum group (Table V).

TABLE I

FREQUENCIES OF ALKALINE PHOSPHATASE GROUPS OF 3 POPULATIONS COMPARED TO OTHER PUBLISHED RESULTS

\begin{tabular}{|c|c|c|c|c|}
\hline & \multicolumn{2}{|c|}{ Pp groups } & \multirow{2}{*}{ Pp $2 \underset{(\%)}{\text { Frequency }}$} & \multirow{2}{*}{$\begin{array}{c}\text { No. } \\
\text { Examined }\end{array}$} \\
\hline & Pp 1 & Pp 2 & & \\
\hline $\begin{array}{l}\text { Montagnais } \\
\text { Naskapi } \\
\text { Sapelo } \\
\text { Adult unrelated Swedes (Arfors et al., 1963, quoted in Beckman, } \\
\text { 1964) } \\
\text { Brazilian population (Beckman, 1964) } \\
\quad \text { Parents } \\
\text { All children }\end{array}$ & $\begin{array}{r}32 \\
48 \\
29 \\
145 \\
369 \\
667\end{array}$ & $\begin{array}{r}82 \\
105 \\
50 \\
55 \\
99 \\
172\end{array}$ & $\begin{array}{l}71 \cdot 9 \\
68 \cdot 6 \\
63 \cdot 3 \\
27 \cdot 5 \\
21 \cdot 2 \\
20 \cdot 5\end{array}$ & $\begin{array}{r}114 \\
153 \\
79 \\
200 \\
468 \\
839\end{array}$ \\
\hline
\end{tabular}

TABLE II

RELATION BETWEEN PHOSPHATASE GROUPS AND $A_{1} A_{2} B O$ BLOOD GROUPS, AND A'S VERSUS NON A OF ABO BLOOD GROUPS

\begin{tabular}{|c|c|c|c|c|c|c|c|c|c|c|c|c|c|}
\hline & $\mathbf{P p}$ & $\mathbf{A}_{1}$ & $\mathbf{A}_{2}$ & B & $\mathbf{A}_{1} \mathbf{B}$ & $\mathbf{A}_{2} \mathbf{B}$ & $\mathbf{O}$ & Total & Probability & $\begin{array}{c}\text { A's } \\
(\mathbf{A}+\mathbf{A B})\end{array}$ & $\begin{array}{l}\text { Non A } \\
(B+\mathbf{O})\end{array}$ & Total & Probability \\
\hline $\begin{array}{l}\text { Montagnais } \\
\text { Naskapi } \\
\text { Sapelo }\end{array}$ & $\begin{array}{l}1 \\
2 \\
1 \\
2 \\
1 \\
1\end{array}$ & $\begin{array}{r}27 \\
8 \\
39 \\
11 \\
8 \\
2\end{array}$ & $\begin{array}{l}0 \\
0 \\
0 \\
0 \\
6 \\
1\end{array}$ & $\begin{array}{l}0 \\
4 \\
0 \\
2 \\
3 \\
6\end{array}$ & $\begin{array}{l}0 \\
0 \\
0 \\
0 \\
0 \\
0\end{array}$ & $\begin{array}{l}0 \\
0 \\
0 \\
0 \\
0 \\
2\end{array}$ & $\begin{array}{r}5 \\
70 \\
9 \\
92 \\
12 \\
38\end{array}$ & $\begin{array}{r}32 \\
82 \\
48 \\
105 \\
29 \\
49\end{array}$ & $\begin{array}{c}<0.0005 \\
<0.0005 \\
0.005-0.001\end{array}$ & $\begin{array}{r}27 \\
8 \\
39 \\
11 \\
14 \\
5\end{array}$ & $\begin{array}{r}5 \\
74 \\
9 \\
94 \\
15 \\
44\end{array}$ & $\begin{array}{r}21 \\
82 \\
48 \\
105 \\
29 \\
49\end{array}$ & $\begin{array}{l}<0.0005 \\
<0.0005 \\
<0.0005\end{array}$ \\
\hline
\end{tabular}


TABLE III

PHOSPHATASE GROUPS AND LEWIS BLOOD GROUPS

\begin{tabular}{lc|c|c|c|c|c}
\hline & $P p$ & $\begin{array}{c}\mathrm{Le} \\
(\mathrm{a}+\mathrm{b}-)\end{array}$ & $\begin{array}{c}\mathrm{Le} \\
(\mathrm{a}+\mathrm{b}-)\end{array}$ & $\begin{array}{c}\mathrm{Le} \\
(\mathrm{a}-\mathrm{b}-)\end{array}$ & Total & Probability \\
\hline Montagnais & 1 & 1 & 17 & 14 & 32 & $<0.0005$ \\
Sapelo & 2 & 0 & 77 & 5 & 82 & $0.005>\mathrm{p}>0.001$ \\
& 2 & 1 & 8 & 13 & 29 & \\
\hline
\end{tabular}

TABLE IV

RELATION BETWEEN PHOSPHATASE GROUPS AND SALIVARY SECRETION OF ABH AND LEWIS SUBSTANCES (SAPELO POPULATION)

\begin{tabular}{|c|c|c|c|c|}
\hline \multirow[b]{2}{*}{$\mathrm{Pp}$} & \multicolumn{2}{|c|}{ ABH Secretion } & \multirow[b]{2}{*}{ Total } & \multirow[b]{2}{*}{ Probability } \\
\hline & Secretor & $\begin{array}{c}\text { Non- } \\
\text { secretor }\end{array}$ & & \\
\hline \multirow[t]{3}{*}{$\begin{array}{l}1 \\
2\end{array}$} & $\begin{array}{r}9 \\
33\end{array}$ & $\begin{array}{r}12 \\
2\end{array}$ & $\begin{array}{l}21 \\
39\end{array}$ & $0.001>p>0.0005$ \\
\hline & \multicolumn{2}{|c|}{ Lewis secretion } & & \\
\hline & Les & $\mathrm{nL}$ & & \\
\hline 1 & $\begin{array}{l}19 \\
25\end{array}$ & $\begin{array}{r}2 \\
14\end{array}$ & $\begin{array}{l}21 \\
39\end{array}$ & $0.05>p>0.025$ \\
\hline
\end{tabular}

Les $=$ secretor of Lewis substance; $\mathrm{nL}=$ non-secretor of Lewis substance.

\section{Discussion}

The frequency of phosphatase group $2(\mathrm{Pp} 2)$ is conspicuously increased in all of our three populations (Montagnais, Naskapi, and Sapelo) when compared to those reported by Arfors et al. (1963a), with an incidence of $27.5 \%$ for $\mathrm{Pp} 2$ in an adult Swedish population, and by Beckman (1964) who reported an incidence of $21.2 \%$ in adults, and $20.5 \%$ in children of a Brazilian population.

The reason for this difference in frequency is almost certainly due to two factors. The first is the increased frequency of blood group $O$ in the populations under investigation (see Table II). This relatively high frequency of the blood group $\mathrm{O}$ in other Indian populations has been recorded (Gates, 1938; Matson and Piper, 1947; Boyd and Boyd, 1949; Chown and Lewis, 1956; Allen and Corcoran, 1960). The second reason lies in the high frequency of secretors in some Indian populations (Boyd and Boyd, 1949; Kaklamani and Holborow, 1963), and the high frequency of the blood group Le $(a-b+)$ (and therefore the high frequency of secretors of $\mathrm{ABH}$ substance), in other Indian populations where secretor status was not directly examined (Chown and Lewis, 1956; Allen and Corcoran, 1960).

The problem of calculating gene frequencies in small populations was discussed by Neel, Salzano,
TABLE V

RELATION BETWEEN PHOSPHATASE GROUPS AND DUFFY (Fya), Js, AND Xg BLOOD GROUPS

\begin{tabular}{|c|c|c|c|c|}
\hline & $\mathbf{P p}$ & Fya+ & Fya- & Probability \\
\hline $\begin{array}{l}\text { Montagnais } \\
\text { Naskapi } \\
\text { Sapelo }\end{array}$ & $\begin{array}{l}1 \\
2 \\
1 \\
2 \\
1 \\
2\end{array}$ & $\begin{array}{r}28 \\
72 \\
47 \\
103 \\
3 \\
3\end{array}$ & $\begin{array}{r}4 \\
10 \\
1 \\
1 \\
26 \\
47\end{array}$ & $\begin{array}{r}0.90 \\
0.60>p>0.50 \\
0.50>p>0.40\end{array}$ \\
\hline Sapelo & & $\mathrm{Js}^{+}$ & $\mathrm{Js}^{--}$ & \\
\hline \multirow[t]{2}{*}{ Sapelo } & $\begin{array}{l}1 \\
2\end{array}$ & $\begin{array}{l}12 \\
15 \\
\end{array}$ & $\begin{array}{l}17 \\
34\end{array}$ & $0.40>p>0.30$ \\
\hline & & $\mathbf{X g}^{\mathrm{a}+}$ & $\mathrm{Xg}^{\mathrm{a}-}$ & \\
\hline Sapelo & $\frac{1}{2}$ & $\begin{array}{l}23 \\
30\end{array}$ & $\begin{array}{r}6 \\
20\end{array}$ & $0.10>p>0.05$ \\
\hline
\end{tabular}

Junqueira, Keiter, and Maybury-Lewis (1964) and Neel (1965). In this it was noted that the methods for calculating gene frequencies, whether applicable only to unrelated subjects or to family data, were based on the assumption that Hardy-Weinberg equilibrium pertained in the population. Neel emphasized that in calculating gene frequencies for such populations, the important question was not whether there was a departure from HardyWeinberg equilibrium conditions, but whether the departure was sufficient to introduce significant errors in calculations of gene frequencies which assume equilibrium. Examination of the $M N$ groups in our three populations where phenotype accurately reflects genotype (i.e., $M, M N$, and $N$ ) showed a good fit to the Hardy-Weinberg expectations. As with Neel's population, this is surprising, as the populations we examined here may also violate some of the prerequisites for Hardy-Weinberg equilibrium (i.e. non-random mating, overlapping generations, and small population).

We have elected here, for the same reasons given by Neel et al. (1964) with his population of Xavante Indians, to calculate the frequency of $\mathrm{Pp} 2$ in these three populations as if they were composed of unrelated people drawn from populations of infinite size in Hardy-Weinberg equilibrium.

Our observations on the ABO and Lewis blood 
groups, and $\mathrm{ABH}$ secretion in the saliva, confirm the previous observations of Arfors et al. (1963b), Beckman (1964), Shreffler (1965), Evans (1965), and Bamford et al. (1965). The association of $\mathrm{Pp} 2$ with the $A B O$ blood groups is seen in all three populations, and with the $A B H$ secretor system in the Sapelo population. Our sample also serves to emphasize that these effects are not absolute and that Pp 2 was detected in some persons of blood group $A$ and also in some persons who were non-secretors of $\mathrm{ABH}$ in their saliva.

No association was found between the Duffy blood group $\left(\mathrm{Fy}^{\mathrm{a}}\right)$ and phosphatase groups in the three populations examined. This confirms the result of Shreffler (1965), who did not find any association, but it is contrary to that of Beckman (1964) who found a higher phosphatase 2 (Pp 2) amongst subjects with the Duffy blood group.

The first highly significant association at the enzyme level has been demonstrated in the recent investigations of the $\mathrm{ABO}$ blood groups in relation to types of serum alkaline phosphatase (Brit. med. F., 1965). Not only have associations of the different types of serum alkaline phosphatase been observed, but also quantitative variations. Bamford $e t$ al. (1965) have shown that in blood groups $O$ and B, with red cells Le $(a-)$-mostly secretors of $A B H$ substance-the average level of serum alkaline phosphatase is $15 \%$ higher than in blood groups A and $A B$. This quantitative increase of alkaline phosphatase, as shown by Bamford et al. (1965), adds support to the hypothesis that the origin of the two types of alkaline phosphatase, fast moving and slow moving, are different, and that in $\mathrm{Pp} 2$, where both bands are present, one would expect, on the average, higher values for levels of alkaline phosphatase. Evidence has been presented by Cunningham and Rimer (1963), Haije and De Jong (1963), Fishman and Kreisher (1963), and Hodson, Latner, and Raine (1962), that the fast-moving phosphatase band present in all individuals is produced in the liver, and that the slow-moving phosphatase band, present only in some subjects, is produced in the jejunal mucosa.

These findings are consistent with the concept that the statistical relation between duodenal ulcer and blood group $\mathrm{O}$ may be related to the presence of a different enzyme system in the jejunum, and not directly to the ABO blood group system.

\section{Summary}

Serum alkaline phosphatase variations were examined on specimens from three populations, Montagnais and Naskapi Indians, and Sapelo Island Negroes, by starch gel electrophoresis.
The action of neuraminidase on the phosphatase bands is presented, and the presence of a pregnancy band was demonstrated in 10 of the persons investigated from the Montagnais and Naskapi.

The frequency of phosphatase 2 ( $\mathrm{Pp} \mathrm{2}$ ) was $71.9 \%$ in the Montagnais, $68.6 \%$ in the Naskapi, and $63.3 \%$ in the Sapelo Island Negroes.

Confirmation of the association between the ABO blood groups and salivary ABH secretor phenotypes with serum alkaline phosphatase was obtained.

No association was observed of the MNSs, Kidd (Jk), Sutter (Js), Xg, and Duffy $\left(F^{a}{ }^{a}\right)$ red cell groups, nor with the Gc serum groups, and the phosphatase groups in the three populations examined.

\section{REFERENCES}

Allen, F. H., Jr., and Corcoran, P. A. (1960). Blood groups of the Penobscot Indians. Amer. F. phys. Anthrop., 18, 109.

Arfors, K.-E., Beckman, L., and Lundin, L.-G. (1963a). Genetic variations of human serum phosphatases. Acta genet. (Basel), 13, 89

- , and - (1963b). Further studies on the association between human serum phosphatases and blood groups. ibid., 13, 366 . Bamford, K. F., Harris, H., Luffman, J. E., Robson, E. B., and Cleghorn, T. E. (1965). Serum-alkaline-phosphatase and the ABO blood-groups. Lancet, 1, 530.

Beckman, L. (1964). Associations between human serum alkaline phosphatases and blood groups. Acta genet. (Basel), 14, 286.

- , and Grivea, M. (1965). Serum alkaline phosphatase variations in pregnant women and newborn children. ibid., 15, 218.

Blumberg, B. S. (1967). Studies on the blood groups of the Negroes on Sapelo Island. In preparation.

-, Martin, J. R., Allen, F. H., Jr., Weiner, J. L., Vitagliano, E. M., and Cooke, A. (1964). Blood groups of the Naskapi and Montagnais Indians of Schefferville, Quebec. Hum. Biol., 36, 263.

Boyd, W. C., and Boyd, L. G. (1949). The blood groups and types of the Ramah Navaho. Amer. F. phys. Anthrop., 7, 569.

Boyer, S. H. (1961). Alkaline phosphatase in human sera and placentae. Science, 134, 1002.

Brit. med. F. (1965). Blood groups and an enzyme. (Leading article.) 2, 435.

Chown, B., and Lewis, M. (1956). The blood group genes of the Cree Indians and the Eskimos of the Ungava District of Canada. Amer. F. phys. Anthrop., 14, 215.

Cunningham, V. R., and Rimer, J. G. (1963). Isoenzymes of alkaline phosphatase of human serum. Biochem. $\mathcal{F} ., 89,50 \mathrm{P}$.

Evans, D. A. P. (1965). Confirmation of association between ABO blood groups and salivary ABH secretor phenotypes and electrophoretic patterns of serum alkaline phosphatase. f. med. Genet., $2,126$.

Fishman, W. H., and Kreisher, J. H. (1963). Stereospecific, organspecific inhibition of intestinal alkaline phosphatase. Ann. N. Y. Acad. Sci., 103, 951.

Gates, R. R. (1938). The blood groups and other features of the Micmac Indians. F. roy. anthrop. Inst., 68, 283.

Haije, W. G., and De Jong, M. (1963). Iso-enzyme patterns of serum alkaline phosphatase in agar-gel electrophoresis and their clinical significance. Clin. chim. Acta, 8, 620.

Harper, F. (1964). The friendly Montagnais and their neighbors in the Ungava Peninsula. University of Kansas Museum of Natural History, Miscellaneous Publication No. 37. University of Kansas, Lawrence, Kansas.

Hodson, A. W., Latner, A. L., and Raine, L. (1962). Iso-enzymes of alkaline phosphatase. Clin. chim. Acta, 7, 255.

Kaklamani, E., and Holborow, E. J. (1963). Secretor and Lewis gene frequencies in Blackfeet Indians. Vox. Sang. (Basel), 8, 231

Matson, G. A., and Piper, C. L. (1947). Distribution if the blood groups, M-N, RH types and secretors among the Ute Indians of Utah. Amer. F. phys. Anthrop., 5, 357. 
Neel, J. V. (1965). Hardy-Weinberg equilibrium and primitive populations. Amer. F. hum. Genet., 17, 92.

-, Salzano, F. M., Junqueira, P. C., Keiter, F., and MayburyLewis, D. (1964). Studies on the Xavante Indians of Brazilian Mato Grosso. ibid., 16, 52.

Poulik, M. D. (1957). Starch gel electrophoresis in a discontinuous system of buffers. Nature (Lond.), 180, 1477.

Race, R. R., and Sanger, R. (1962). Blood Groups in Man, 4th ed., p. 243. Blackwell Scientific Publications, Oxford

Rasmusen, B. A. (1965). Inheritance of R-O-i blood groups and alkaline phosphatase polymorphism in sheep. Genetics, 51, 767.

Rendel, J., Aalund, O., Freedland, R. A., and Møller, F. (1964). The relationship between alkaline phosphatase polymorphism and blood group $\mathrm{O}$ in sheep. ibid., 50,973.

-, and Gahne, B. (1963). Interaction between phophatases and the J blood group in cattle. Immunogenet. Lett., 3, 38 .

, and Stormont, C. (1964). Variants of ovine alkaline serum phosphatases and their association with the R-O blood groups. Proc. Soc. exp. Biol. (N.Y.), 115, 853.

Robinson, J. C., and Pierce, J. E. (1964). Differential action of neuraminidase on human serum alkaline phosphatases. Nature (Lond.), 204, 472.

,-- , and Blumberg, B. S. (1966). The serum alkaline phosphatase of pregnancy. Amer. F. Obstet. Gynec., 94, 559.

Shreffler, D. C. (1964). Blood group-associated variation in a human serum alkaline phosphatase component. Program for the American Society of Human Genetics, Boulder, Colorado.

- (1965). Genetic studies of blood group-associated variations in a human serum alkaline phosphatase. Amer. F. hum. Genet., 17, 71.

Smithies, O. (1955). Zone electrophoresis in starch gels: group variations in the serum proteins of normal human adults. Biochem. f., 61, 629. 